\title{
Dioxygen Activation by Copper-Bleomycin: Theoretical Considerations
}

\author{
Radu Silaghi-Dumitrescu,* Mihai Surducan, and Anita Papp \\ Department of Chemistry, “Babes,-Bolyai” University, 11 Arany Janos str, Cluj-Napoca, RO-400028, Romania
}

Abstract. Density functional theory (DFT) calculations are employed to calculate probable reaction intermediates in dioxygen activation by bleomycin-ligated copper - $\mathrm{Cu}(\mathrm{I})$-dioxygen, $\mathrm{Cu}(\mathrm{I})$-superoxo and $\mathrm{Cu}$ (II)-hydroperoxo. The electronic structures of these intermediates are discussed with emphasis on their electromerism. Importantly, unlike in dioxygen activation by iron-bleomycin, formation of these reactive intermediates requires that some of the copper-bleomycin bonds be broken. (doi: 10.5562/cca1793)

Keywords: bleomycin, DFT, copper-peroxo, copper-hydroperoxo, dioxygen activation

\section{INTRODUCTION}

Bleomycin is a drug whose action involves chelating a metal center and then damaging DNA within living cells. A key intermediate in bleomycin's anti-DNA action is a species known as activated bleomycin, ABLM, which, on the basis of spectroscopic and theoretical studies, appears well described as a bleomycin-ferric-hydroperoxo adduct ( $c f$. Figure 1). ABLM's instability has to some extent precluded detailed structural characterization, ${ }^{1-3}$ but its formation is generally accepted to entail reaction of ferrous bleomycin with molecular oxygen, followed by a oneelectron reduction to yield a formally ferrous-superoxo adduct, whose protonation would lead to ABLM. A somewhat more stable cognate, the $\mathrm{Co}(\mathrm{III})$-hydroperoxo bleomycin adduct, has been characterized spectroscopically, and its inferred structural features appear very similar to those of ABLM. ${ }^{4-12}$

Copper is also known to activate bleomycin and attack DNA in a similar way to (but less much

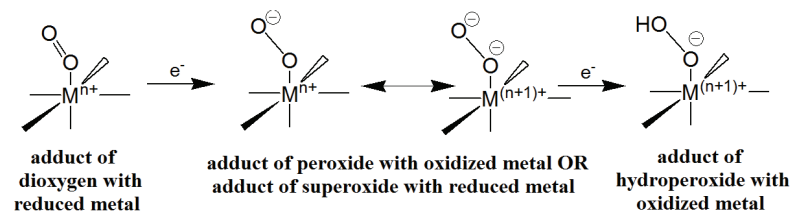

Figure 1. Dioxygen activation by protonation and reduction with transition metals in bleomycin-type coordination environments. The metal $\mathrm{M}$ may be iron (II, III) although other metals may perform similar chemistries (e.g., copper). The hydroperoxo species is known as ABLM in iron-bleomycin. efficiently than) iron-bleomycin. ${ }^{13}$ Structural data on $\mathrm{Cu}$-bleomycin is available showing that copper binds in a very similar way to iron, ${ }^{14,15}$ with some indication for partial deligation of the amide nitrogen from $\mathrm{Cu}(\mathrm{I})$ under certain conditions, supported also by molecular dynamics calculations. ${ }^{17}$ Nevertheless, essentially nothing is known on possible reactive intermediates during dioxygen activation by $\mathrm{Cu}$-bleomycin. Here, density functional theory (DFT) calculations are reported on such reactive intermediates, providing a comparison with the iron system.

\section{METHODS}

Figure 2 shows the models employed in the present work. The bleomycin ligand is modelled as one single chelating unit, comprising all of the potential metalbinding atoms from bleomycin. Bleomycin additionally contains sugar and sulphur-based aromatic systems, which are not included in our models especially as they were also not included in computational models of iron systems by others. ${ }^{3}$ Three states at the copper were examined: copper(I) bound to neutral $\mathrm{O}_{2}(S=0$ multiplicity for the adduct), its one-electron reduced version (formally $\mathrm{Cu}(\mathrm{I})$ bound to superoxide, $S=1 / 2$ ), and $\mathrm{Cu}(\mathrm{II})$ bound to hydroperoxide $(S=1 / 2)$.

Geometry optimization was performed with the B3LYP density functional ${ }^{17-20}$ with the $6-31 \mathrm{G}^{* *}$ basis set as implemented in Spartan. ${ }^{21}$ For the SCF calculations, a fine grid was used, and the convergence criteria were set to $10^{-6}$ (for the root mean square of electron density) and $10^{-8}$ (energy), respectively. For geometry

\footnotetext{
* Author to whom correspondence should be addressed. (E-mail: rsilaghi@chem.ubbcluj.ro)
} 


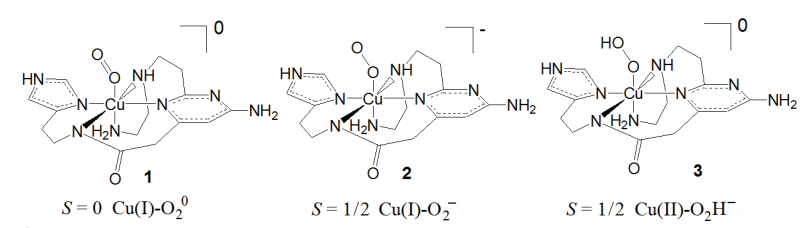

Figure 2. Models employed in the present study.

optimization, convergence criteria were set to 0.001 a.u. (maximum gradient criterion) and 0.0003 (maximum displacement criterion).

\section{RESULTS AND DISCUSSION}

Table 1 lists key calculated geometrical parameters for the models of Figure 2, as well as results on reference models of $\mathrm{Cu}(\mathrm{I})$ and $\mathrm{Cu}(\mathrm{II})$ bleomycin without a dioxygenic $\left(\mathrm{O}_{2}\right.$ or $\mathrm{OO}^{-}$or $\left.\mathrm{OOH}^{-}\right)$ligand. One important feature is the fact that dioxygen binding and reduction at the bleomycin-bound copper appears to entail cleavage of at least one copper-nitrogen bonds, as expected since these intermediates would imply coordination numbers distinctly higher than those normally preferred by copper - even though prior to dioxygen binding according to experimental data $\mathrm{Cu}$ (II) binds to bleomycin in a manner essentially identical to iron or cobalt, in pentacoordinated manner. ${ }^{14,15}$ Thus, two coppernitrogen bonds are broken in the $\mathrm{Cu}(\mathrm{I})$ dioxygen (1) (bond lengths longer than $3.5 \AA$ towards the imidazole ring and towards the amine nitrogen trans to the initial empty coordination position). Only the latter bond is clearly broken in models $\mathbf{2}$ and $\mathbf{3}$. Additionally, the bond between the copper and the amine nitrogen cis to the dioxygenic ligand is $\sim 2.5 \AA$ in all three models, which is at the limits of what can be described as coordinative copper-nitrogen bonding. This cleavage of coppernitrogen bonds in models $\mathbf{1 - 3}$ is an important difference to the behaviour of iron- and cobalt-bleomycin, where formation of hydroperoxo adducts did not require cleavage of metal-bleomycin bonds. ${ }^{1,3,5,9}$

The O-O bond in model $\mathbf{1}$ is $1.38 \AA$ for $S=0$ and

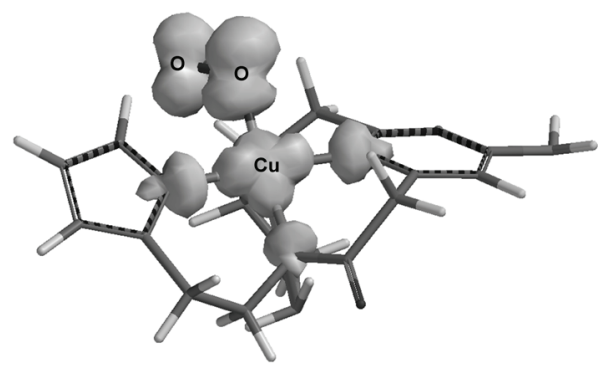

Figure 3. Spin density in model 2.
1.33 for $S=1$, consistent with what is measured at this level of theory for a superoxide molecule $(1.35 \AA$ for free $\mathrm{O}_{2}{ }^{-}$and $1.33 \AA$ for $\mathrm{OOH}^{0}$ ), and $0.16 \AA$ longer than the bond length within a free dioxygen molecule (1.22 $\AA$ for $S=1 \mathrm{O}_{2}$ ). As such, one may conclude that binding of dioxygen to $\mathrm{Cu}(\mathrm{I})$ bleomycin has resulted in an electron transfer, so that the adduct is better described as $\mathrm{Cu}(\mathrm{II})$-superoxo - much like the adduct of ferrous hemoglobin with dioxygen is better described as

Table 1. Key DFT-derived distances and angles ( $\AA$ and ${ }^{\circ}$, respectively) for models employed in the present study

\begin{tabular}{|c|c|c|c|}
\hline \multicolumn{4}{|c|}{$\mathbf{1}, S=0 \mathrm{Cu}(\mathrm{I})-\mathrm{OO}^{0}$} \\
\hline $\mathrm{Cu}-\mathrm{O}$ & $1.82 / 1.86^{(\mathrm{d})}$ & $\mathrm{Cu}-\mathrm{N}(\text { amide })^{(\mathrm{b})}$ & 1.90 \\
\hline $\mathrm{O}-\mathrm{O}$ & 1.38 & $\mathrm{Cu}-\mathrm{N}(\mathrm{imid})^{(\mathrm{c})}$ & 3.78 \\
\hline $\mathrm{Cu}-\mathrm{O}-\mathrm{O}$ & $69^{\circ}$ & $\mathrm{Cu}-\mathrm{N}(\mathrm{py})^{(\mathrm{d})}$ & 1.94 \\
\hline $\mathrm{Cu}-\mathrm{N}(c i s)^{(\mathrm{a})}$ & 2.46 & $\mathrm{Cu}-\mathrm{N}(\text { trans })^{(\mathrm{a})}$ & 3.83 \\
\hline \multicolumn{4}{|c|}{$\mathbf{1}, S=1 \mathrm{Cu}(\mathrm{I})-\mathrm{OO}^{0}$} \\
\hline $\mathrm{Cu}-\mathrm{O}$ & $2.08 / 2.90^{(\mathrm{d})}$ & $\mathrm{Cu}-\mathrm{N}(\text { amide })^{(\mathrm{b})}$ & 1.95 \\
\hline $\mathrm{O}-\mathrm{O}$ & 1.33 & $\mathrm{Cu}-\mathrm{N}(\mathrm{imid})^{(\mathrm{c})}$ & 3.52 \\
\hline $\mathrm{Cu}-\mathrm{O}-\mathrm{O}$ & $115^{\circ}$ & $\mathrm{Cu}-\mathrm{N}(\mathrm{py})^{(\mathrm{d})}$ & 2.07 \\
\hline $\mathrm{Cu}-\mathrm{N}(c i s)^{(\mathrm{a})}$ & 2.07 & $\mathrm{Cu}-\mathrm{N}(\text { trans })^{(\mathrm{a})}$ & 2.15 \\
\hline \multicolumn{4}{|c|}{$2^{(\mathrm{e})}, S=1 / 2 \mathrm{Cu}(\mathrm{I})-\mathrm{OO}^{-}$} \\
\hline $\mathrm{Cu}-\mathrm{O}$ & $1.93 / 1.93^{(\mathrm{d})}$ & $\mathrm{Cu}-\mathrm{N}(\text { amide })^{(\mathrm{b})}$ & 2.00 \\
\hline $\mathrm{O}-\mathrm{O}$ & 1.46 & $\mathrm{Cu}-\mathrm{N}(\mathrm{imid})^{(\mathrm{c})}$ & 3.91 \\
\hline $\mathrm{Cu}-\mathrm{O}-\mathrm{O}$ & $68^{\circ}$ & $\mathrm{Cu}-\mathrm{N}(\mathrm{py})^{(\mathrm{d})}$ & 2.06 \\
\hline $\mathrm{Cu}-\mathrm{NH}_{2}(c i s)^{(\mathrm{a})}$ & 2.62 & $\mathrm{Cu}-\mathrm{N}(\text { trans })^{(\mathrm{a})}$ & 4.24 \\
\hline \multicolumn{4}{|c|}{$3, S=1 / 2 \mathrm{Cu}(\mathrm{II})-\mathrm{OOH}$} \\
\hline $\mathrm{Cu}-\mathrm{O}$ & $1.93 / 2.65^{(\mathrm{d})}$ & $\mathrm{Cu}-\mathrm{N}(\text { amide })^{(\mathrm{b})}$ & 1.96 \\
\hline $\mathrm{O}-\mathrm{OH}$ & 1.47 & $\mathrm{Cu}-\mathrm{N}(\mathrm{imid}){ }^{(\mathrm{c})}$ & 2.03 \\
\hline $\mathrm{Cu}-\mathrm{O}-\mathrm{OH}$ & $102^{\circ}$ & $\mathrm{Cu}-\mathrm{N}(\mathrm{py})^{(\mathrm{d})}$ & 2.06 \\
\hline $\mathrm{Cu}-\mathrm{N}(c i s)^{(\mathrm{a})}$ & 2.59 & $\mathrm{Cu}-\mathrm{N}(\text { trans })^{(\mathrm{a})}$ & 3.69 \\
\hline \multicolumn{4}{|c|}{$4, S=0 \mathrm{Cu}(\mathrm{I})$} \\
\hline $\mathrm{Cu}-\mathrm{O}$ & - & $\mathrm{Cu}-\mathrm{N}(\text { amide })^{(\mathrm{b})}$ & 1.98 \\
\hline $\mathrm{O}-\mathrm{O}$ & - & $\mathrm{Cu}-\mathrm{N}(\mathrm{imid})^{(\mathrm{c})}$ & 2.01 \\
\hline $\mathrm{Cu}-\mathrm{O}-\mathrm{O}$ & - & $\mathrm{Cu}-\mathrm{N}(\mathrm{py})^{(\mathrm{d})}$ & 1.96 \\
\hline $\mathrm{Cu}-\mathrm{N}(c i s)^{(\mathrm{a})}$ & 3.00 & $\mathrm{Cu}-\mathrm{N}(\text { trans })^{(\mathrm{a})}$ & 2.17 \\
\hline \multicolumn{4}{|c|}{$5, S=1 / 2 \mathrm{Cu}(\mathrm{II})$} \\
\hline $\mathrm{Cu}-\mathrm{O}$ & - & $\mathrm{Cu}-\mathrm{N}(\text { amide })^{(\mathrm{b})}$ & 1.92 \\
\hline $\mathrm{O}-\mathrm{O}$ & - & $\mathrm{Cu}-\mathrm{N}(\mathrm{imid})^{(\mathrm{c})}$ & 2.07 \\
\hline $\mathrm{Cu}-\mathrm{O}-\mathrm{O}$ & - & $\mathrm{Cu}-\mathrm{N}(\mathrm{py})^{(\mathrm{d})}$ & 2.02 \\
\hline $\mathrm{Cu}-\mathrm{N}(c i s)^{(\mathrm{a})}$ & 2.16 & $\mathrm{Cu}-\mathrm{N}(\text { trans })^{(\mathrm{a})}$ & 2.26 \\
\hline $\begin{array}{l}\text { a) Positions cis ar } \\
\text { b) Amide nitroger } \\
\text { c) Imidazole nitro } \\
\text { d) Distances to bo } \\
\text { e) A bidentate ve } \\
\text { Nas } 16 \text { kcal mol } \\
\text { urther. }\end{array}$ & $\begin{array}{l}\text { trans relative } \\
\text { atom. } \\
\text { hen atom. } \\
\text { oxygen atom } \\
\text { ion of the mo } \\
\text { less stable an }\end{array}$ & $\begin{array}{l}\text { o the } \mathrm{OOH} \text { ligand. } \\
\text { are shown. } \\
\text { l was also identif } \\
\text { is hence not disc }\end{array}$ & wh \\
\hline
\end{tabular}


Table 2. Key DFT-derived partial charges and spins from NPA (spin given in brackets)

\begin{tabular}{cccc}
\hline & \multicolumn{3}{c}{ Partial charge (spin) } \\
\hline $\begin{array}{c}\text { Model / Formal } \\
\text { description }\end{array}$ & $\begin{array}{l}\text { Spin } \\
\text { state }\end{array}$ & $\mathrm{Cu}$ & $\mathrm{O}_{2}$ or $\mathrm{OOH}$ \\
\hline $\mathbf{1} / \mathrm{Cu}(\mathrm{I})-\mathrm{OO}^{0}$ & $S=0$ & $1.42(0.00)$ & $-0.84(0.00)$ \\
& $S=1$ & $1.40(0.67)$ & $-0.73(1.1)$ \\
$\mathbf{2} / \mathrm{Cu}(\mathrm{I})-\mathrm{OO}^{-}$ & $S=1 / 2$ & $1.26(0.48)$ & $-1.26(0.46)$ \\
$\mathbf{3} / \mathrm{Cu}(\mathrm{II})-\mathrm{OOH}$ & $S=1 / 2$ & $1.42(0.67)$ & $-0.75(0.21)$ \\
\hline
\end{tabular}

ferric-superoxo. ${ }^{22,23}$ The partial atomic charges shown in Table 2 for the oxygen atoms in model 1 indeed reveal negative charge; whereas in the $S=0$ state antiferromagnetic coupling is problematic in terms of population analyses, in the $S=1$ state the 1.1 spin units on the $\mathrm{O}_{2}$ ligand are clearly in line with a superoxide ligand rather than with a $\mathrm{O}_{2}$ molecule (be it singlet or triplet). Interestingly, the $S=0$ was found to feature a bidentate $\mathrm{O}_{2}$ ligand, whereas the $S=1$ state featured a monodentate $\mathrm{O}_{2}$; in both cases a local minimum corresponding to the alternative hapticity isomer could not be located. The $S=1$ was found to be more stable than $S=0$ by $13 \mathrm{kcal} \mathrm{mol}^{-1}$.

The $\mathrm{O}-\mathrm{O}$ bond in model 2 is $1.45 \AA$, similar to what is predicted at the same level of theory for a peroxo ligand $^{22,24,25}$ and longer by $\sim 0.1 \AA$ than the superoxide-like bond predicted in model $\mathbf{1}$. This suggests that model 2 may be described as $\mathrm{Cu}(\mathrm{II})-\mathrm{O}_{2}{ }^{2-}$, as opposed to $\mathrm{Cu}(\mathrm{I})-\mathrm{O}_{2}{ }^{-}$. Thus, at this stage the dioxygen molecule has been reduced by two electrons - which is the most one can achieve in terms of activating $\mathrm{O}_{2}$ with a biological copper center. ${ }^{26}$ In fact the O-O bond in this copper(II)-peroxo model is distinctly longer than the $1.33-1.36 \AA$ seen in related Fe(III)-peroxo models in heme and non-heme environment. ${ }^{3,24,25}$ The geometrical parameters within the $\mathrm{Cu}-\mathrm{O}-\mathrm{O}-(\mathrm{H})$ moiety in 3, and especially the $1.47 \AA \mathrm{O}-\mathrm{O}$ distance, are generally in line with previously reported data on related species, showing a clean $\mathrm{Cu}$-hydroperoxo structure, ${ }^{26}$ as also supported by the negative charge on the $\mathrm{OOH}$ (equal in magnitude to the charge computed for the superoxo ligand in 1) and by the negligible spin density $(0.26$ units).

Figure 3 illustrates the spin density in model 2. The unpaired electron appears distributed in a manner drastically different from what is seen typically in related $\mathrm{Fe}(\mathrm{II})$-superoxo / Fe(III)-peroxo adducts. Thus, in model 2 the spin density at the oxygen atoms is distributed mostly in orbitals located in the metal-oxygenoxygen plane, while in the iron counterpart it is distributed perpendicular to this plane. ${ }^{24,27,28}$ The values of the spin density computed on the two oxygen atoms highlighted in Figure 3 are 0.27 and 0.12 , respectively, amounting to less than 0.5 and consistent with the geometrical data of Table 1 in predicting an $S=1 / 2$ copper center (hence, $\mathrm{Cu}(\mathrm{II})$ ) bound to a diamagnetic peroxo ligand - albeit with strong mixing between the orbitals of the metal and peroxide.

\section{CONCLUSION}

To conclude, the density functional theory data shown here predicts that dioxygen activation by copperbleomycin will require deligation of two of the bleomycin ligands away from the copper - which is a notable difference compared to the pathway followed for the same reaction by iron bleomycin. Another important difference is in the fact that the $\mathrm{Cu}(\mathrm{I})$-superoxo/ $\mathrm{Cu}$ (II)-peroxo has a distinctly clearer peroxo character at the ligand, compared to related $\mathrm{Fe}(\mathrm{II})$-superoxo / $\mathrm{Fe}(\mathrm{III})$-peroxo moieties previously described at the same level of theory.

Acknowledgements. Funding from the Romanian Ministry of Education and Research, (grant PCCE 140/2008) and from a PhD scholarship (to MS, Contract POSDRU/88/1.5/S/60185 "Innovative doctoral studies in a knowledge based society") is gratefully acknowledged.

\section{REFERENCES}

1. A. Decker, M. S. Chow, J. N. Kemsley, N. Lehnert, and E. I. Solomon, J. Am. Chem. Soc. 128 (2006) 4719-4733.

2. J. N. Kemsley, K. L. Zaleski, M. S. Chow, A. Decker, E. Y. Shishova, E. C. Wasinger, B. Hedman, K. O. Hodgson, and E. I. Solomon, J. Am. Chem. Soc. 125 (2003) 10810-10821.

3. N. Lehnert, F. Neese, R. Y. Ho, L. Que, Jr., and E. I. Solomon, J. Am. Chem. Soc. 124 (2002) 10810-10822.

4. K. D. Goodwin, M. A. Lewis, E. C. Long, and M. M. Georgiadis, Proc. Natl. Acad. Sci. US A 105 (2008) 5052-5056.

5. P. M. Kozlowski, V. V. Nazarenko, and A. A. Jarzecki, Inorg. Chem. 45 (2006) 1424-1426.

6. 6C. Rajani, J. R. Kincaid, and D. H. Petering, J. Am. Chem. Soc. 126 (2004) 3829-3836.

7. C. Xia, F. H. Forsterling, and D. H. Petering, Biochemistry 42 (2003) 6559-6564.

8. C. Zhao, C. Xia, Q. Mao, H. Forsterling, E. DeRose, W. E. Antholine, W. K. Subczynski, and D. H. Petering, J. Inorg. Biochem. 91 (2002) 259-268.

9. T. E. Lehmann, J. Biol. Inorg. Chem. 7 (2002) 305-312.

10. C. Rajani, J. R. Kincaid, and D. H. Petering, Biophys. Chem. 94 (2001) 219-236.

11. W. Li, C. Zhao, C. Xia, W. E. Antholine, and D. H. Petering, Biochemistry 40 (2001) 7559-7568.

12. F. Fedeles and M. Zimmer, Inorg. Chem. 40 (2001) 1557-1561.

13. T. Suzuki, J. Kuwahara, and Y. Sugiura, Biochemistry 24 (1985) 4719-4721.

14. M. Sugiyama, T. Kumagai, M. Hayashida, M. Maruyama, and Y. Matoba, J. Biol. Chem. 277 (2002) 2311-2320.

15. N. Danshiitsoodol, C. A. de Pinho, Y. Matoba, T. Kumagai, and M. Sugiyama, J. Mol. Biol. 360 (2006) 398-408.

16. T. E. Lehmann, J. Biol. Inorg. Chem. 9 (2004) 323-334.

17. A. D. Becke, Phys. Rev. A 38 (1988) 3098-3100.

18. C. Lee, W. Yang, and R. G. Parr, Phys. Rev. B 37 (1988) 785-789. 
19. S. H. Vosko, L. Wilk, and M. Nusair Can, J. Phys. 58 (1980) 1200-1211.

20. P. J. Stephens, F. J. Devlin, C. F. Chabalowski, and M. J. Frisch, J. Phys. Chem. 98 (1994) 11623-11627.

21. SPARTAN '06 for Windows, Wavefunction Inc., 18401 Von Karman Avenue, Suite 370 Irvine, CA 92612,

22. R. Silaghi-Dumitrescu and I. Silaghi-Dumitrescu, J. Inorg. Biochem. 100 (2006) 161-166.

23. D. M. Kurtz, Jr.,. Essays in Biochemistry (1999) 55-80.
24. R. Silaghi-Dumitrescu, I. Silaghi-Dumitrescu, E. D. Coulter, and D. M. Kurtz, Jr., Inorg. Chem. 42 (2003) 446-456.

25. R. Silaghi-Dumitrescu and C. E. Cooper, Dalton Trans. (2005) 3477-3482.

26. L. M. Mirica, X. Ottenwaelder, and T. D. Stack, Chem Rev. 104 (2004) 1013-1045.

27. R. Silaghi-Dumitrescu, J. Biol. Inorg. Chem. 9 (2004) 471-476.

28. R. Silaghi-Dumitrescu, J. Mol. Graph. Model. 28 (2009) 156-161. 